\title{
OCEANOGRAPHY AND SUSPENDED MATERIAL IN TODOS OS SANTOS BAY*
}

\author{
KENNETH M. WOLGEMUTH**, WILLIAM C. BURNETT*** e PAULO LARANJEIRA DE MOURA****
}

\begin{abstract}
Todos os Santos Bay is a large bay $\left(800 \mathrm{~km}^{2}\right)$ located adjacent to the city of Salvador, Bahia. The margins of the bay are undergoing rapid industrial development by both the public and private sectors. This paper presents the general oceanographic conditions in the bay based upon the distribution of temperature, salinity and total suspended material. The salinity distributions obtained from cruises during March, May, and September, 1977, show that the main body of the bay is dominated by marine conditions. Brackish water and estuarine conditions occur only within the channels of the Paraguaçu River and Subaé River, the dominant sources of fresh water into the bay for short periods of time. The distribution of suspended material ranges generally between $0.5-2 \mathrm{mg} / \mathrm{l}$ in the eastern region of the bay with an average of $1.5 \mathrm{mg} / \mathrm{l}$ based on 99 samples. The western part of the bay, which receives water from the Paraguaçu River and Subae River, has an average of $3.8 \mathrm{mg} / 1$ based on 27 samples. Within the channel of the Paraguaçu River, values range between $10-70 \mathrm{mg} / \mathrm{l}$, depending on location and river flow. Vertical profiles of suspended material in the bay often show increasing concentration with depth, apparently due to resuspension by tidal currents. Suspended material concentrations in near-bottom waters during different stages of tidal cycles indicate that resuspended sediments may dominate the particulate load in some areas while having a negligible contribution elsewhere. Approximately $90 \%$ of the suspended material is deposited from waters with salinities of less than $30 \%$. It is estimated that no more than $10 \%$ of the suspended material is transported out onto the continental shelf.
\end{abstract}

RESUMO A Baía de Todos os Santos, Bahia, compreende uma área de aproximadamente $800 \mathrm{~km}^{2}$. Em suas margens está ocorrendo um rápido desenvolvimento industrial. Este trabaIho apresenta as condições oceanográficas gerais da baía, baseando-se sobretudo na distribuição da salinidade e da quantidade total de material em suspensão, sendo observado um total de $\mathbf{4 5 0}$ amostras. A distribuição da salinidade obtida de alguns cruzeiros realizados durante março, maio e setembro de 1977 mostra que toda a baía é dominada por condiçóes marinhas. Água salobra e condiçðes estuarinas ocorrem ao longo dos canais dos rios Paraguaçu e Subaé, os quais se constituem nas principais fontes de água doce para dentro da baia. Durante os fortes aguaceiros, águas com baixos valores de salinidade ocorrem ao longo das margens só por curtos períodos de tempo. Na região leste da baía, a distribuição do material em suspensão varia geralmente de $0,5-2,0 \mathrm{mg} / \mathrm{l} \mathrm{com}$ uma média de $1,5 \mathrm{mg} / \mathrm{l}$. A parte oeste, que acoThe as águas do Rio Paraguaçu e do Rio Subaé, apresenta uma média de $3,8 \mathrm{mg} / 1$. Dentro do canal do Rio Paraguaçu, os valores alcançam $10-70 \mathrm{mg} / \mathrm{l}$, dependendo da localização e do fluxo do rio. Perfis verticais de material em suspensão freqüentemente mostram crescimento da concentração com a profundidade, devido sobretudo ao processo de ressuspensão pelas correntes de maré.

INTRODUCTION Todos os Santos Bay is a large bay in Northeast Brazil with a total area of approximately 800 $\mathrm{km}^{2}$ encircled by about $200 \mathrm{~km}$ of coastline (Fig. 1). Rapid industrial development is occurring along the margins of the bay which will have an increasing impact during the next decade. This paper presents the general oceanography and distribution of suspended material in the estuary.

Salvador is located on a peninsula that borders the channel into Todos os Santos Bay. A city of over 1 million inhabitants, Salvador is the major population center in the otherwise rural area, and one of the important ports of Northeast Brazil. It was a port-of-call of the H.M.S. Challenger in 1873 (Fig. 2). Although the British scientists spent several days here, no oceanographic measurements were made in the estuary.

A knowledge of the quantity of suspended material and its composition is essential to trace the paths of chemical species occurring at the river-ocean interface and the fate of man-made pollutants. Schubel $(1968,1971$ and 1972), for example, has extensively studied the suspended sediment distribution in the Chesapeake Bay. More recently, Schubel and Hirschberg (1977) have used $\mathrm{Pb}-210$ determined sedimentation rates to calculate the rates of accumulation of metals within the estuarine sediments. Using Pb-210 as a tracer, Benninger et al. (1975) have shown that, at least for lead, the flux to the open ocean from a drowned-river estuary must be very small.

\footnotetext{
* Programa de Pesquisa e Pós-graduação em Geofísica, Universidade Federal da Bahia, Salvador, Bahia

** Amerada Hess Corp., P.O. Box 2040, Tulsa, Oklahoma 74102, USA

*** Department of Oceanography, The Florida State University, Tallahassee, Florida 32306, USA

**** Departamento de Geociências da U.F.C., Campus do Pici, Bloco 913, CEP 60000, Fortaleza, Ceará, Brasil
} 


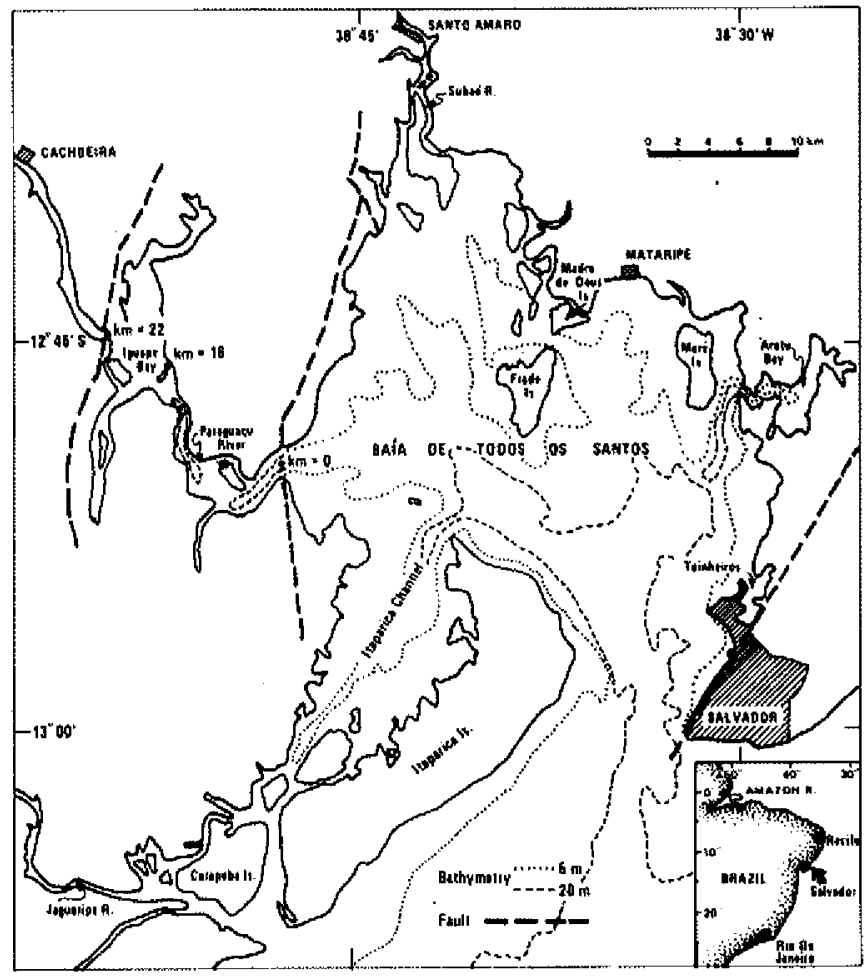

Figure I - Location of Todos os Santos Bay including approximate depth contours

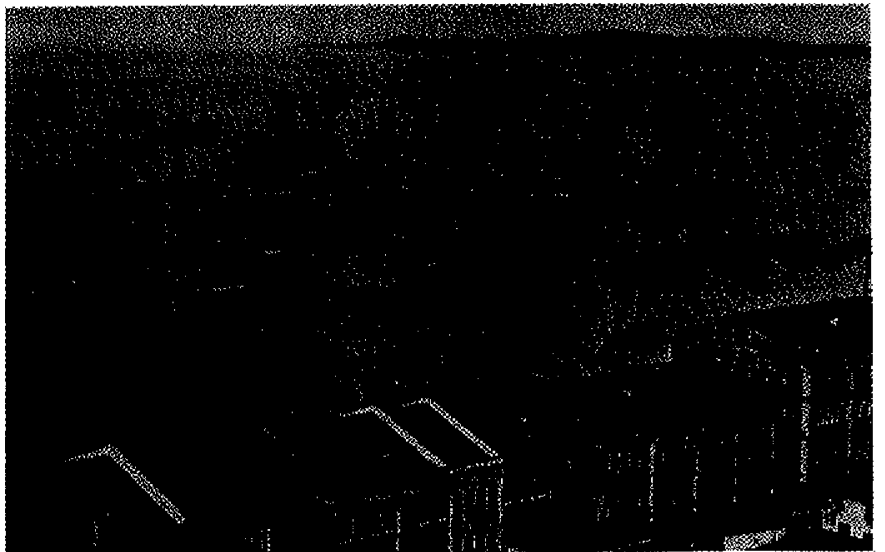

A

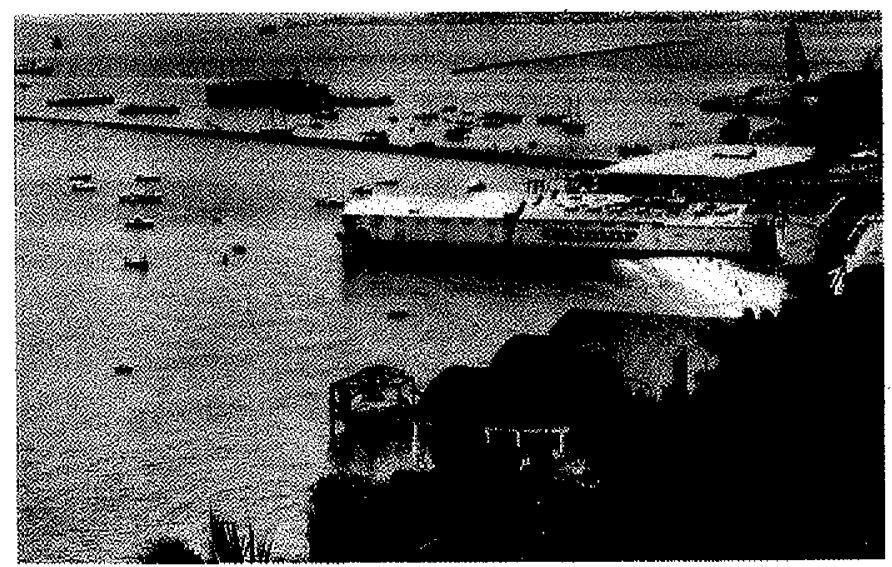

B

Figure 2 - View of Salvador harbor in 1873 (A) and today (B) (1873 picture used by permission of the Trustees of the British Museum - Natural History)
Apparently the particulate load, a mixture of clays and organic material, serves as an effective scavenger for certain dissolved heavy metals.

Some work has been published on the sediment characteristics in Todos os Santos Bay (Bittencourt et al., 1974 and 1976). Barretto and Summerhayes (1975) reported on concentrations and sources of suspended material in continental shelf waters off Northeast Brazil. Our goals have been to study the sources and composition of suspended sediments within the bay and to evaluate the transport of selected trace metals. Trace metal results will be reported elsewhere (Burnett, in prep.).

In order to characterize the general oceanography and distribution of suspended material in Todos os Santos Bay, we completed seven cruises ( $\mathrm{Cl}-$ March 2 and 3; $\mathrm{C} 2$ - March 23; C3 - May 6; C4 - May 13; C5 - May 16-18; C6 - May 20; and C7 - September 15-17) on the $R / V$ Caruana to various sections of the bay during 1977 . The Caruana is a $15 \mathrm{~m}$ former fishing vessel which is now being operated by the Graduate and Research Programs in Geophysics at Federal University of Bahia(UFBa). During our seven excursions, we occupied a total of over 160 stations including forty hydrographic profiles. In all, we have filtered approximately 450 water samples for total suspended material measurements. For another day of sampling, one of us was invited to join Det Norske Verjtas Ltda. on November 11, 1977, while they were carrying out current measurements. This provided the opportunity to obtain suspended material and current velocity data during a maximum in tidal range.

General description of Todos os Santos Bay The bay is located in a graben between Precambrian rocks to the east and west, and extends some $80 \mathrm{~km}$ landward. Although numerous north-south trending faults occur, the dominant ones that define the limits of the bay can be seen on Fig. 1. Several small bays and rivers associated with Todos os Santos Bay have an influence on the salinity and the suspended material. These will be discussed, starting from Salvador and proceeding counterclockwise.

Tainheiros is a small bay only $3 \mathrm{~km}^{2}$ and a locality of significant mercury contamination (Tavares et al., 1977). The mercury is derived from a sodium hydroxide and chlorine producing plant which was operating for approximately twelve years. Production has been discontinued recently and the burden of mercury in sediments is presently being evaluated. In addition, unknown but apparently large quantities of raw sewage enter Tainheiros from Salvador, especially from a community of about 100,000 people who live on landfill and houses built on stilts over the water which discharge waste directly into the Tainheiros. Since this sewage is surface flow, it will be almost impossible to estimate the volume. It is, however, a significant pollutant. The obvious health risk is that the population on the landfill gathers its primary protein source, a small clam, from within this bay, as well as bathing in it.

Aratu Bay, a small bay about $26 \mathrm{~km}$ from Salvador, will eventually be in the center of the largest industrial region of Northeast Brazil. A cement plant has already been in operation in the area for approximatelly twenty years and several other industries are now under development. The source of the lime for the cement plant is a submerged carbonate bank composed mainly of mollusc 
shells, found south of Maré Island where it is dredged and hauled into Aratu by barge. Oil production platforms are being constructed along the channel into Aratu and a chemical complex built by the Dow Química Ltda. will soon commence discharging well-treated effluent.

In the northeast part of the bay, Petrobrás operates a refinery at Mataripe and port and tank farms on Madre de Deus Island.

The northwest part of Todos os Santos Bay is under the influence of the Subae River, the second most important source of fresh water into the bay. It has been reported that a lead refinery upriver at Santo Amaro has released large but unknown amounts of lead and cadmium into the river. One newspaper account has reported that approximately four hundred tons of cadmium had been released during the life of the plant. The state environmental protection agency is studying this problem and will probably issue some control measures. It is as yet unknown how far these metals have migrated into the bay.

The Paraguaçu River provides the largest fresh water source into the bay. Since this river is the only true estuarine system in this region, i.e. where significant amounts of fresh water are mixed with saline water, much of our study was devoted to this area. For convenience, Fig. 1 includes kilometer markings starting at the river mouth and progressing upstream. From $\mathrm{km}=0$ to 16 has been designated the lower Paraguaçu, from $\mathrm{km}=16$ to 22 is Iguape Bay, and $>22$, the Upper Paraguaçu. The Iguape Bay is formed by one of the steps of a fault zone on the western side of the graben.

The Itaparica Channel separates Itaparica Island from the mainland to the west. It permits only a very small percentage of tidal flow into the bay, probably less than $5 \%$. In the south end of the channel, a feasibility study for oyster farming is being conducted by the Biology Institute of UFBa.

METHODS The temperature and salinity data were obtained with a Beckman Electrodeless Induction Salinometer (Model RS 5-3). Temperature-salinity measurements were made in all surface water samples immediately after being brought on board by placing the conductivity probe directly in the plastic bucket used for collection of surface water samples. In situ measurements were also made at hydrocast stations up to the maximum length of the conductor cable $(12 \mathrm{~m})$. The Beckman Salinometer was calibrated against a $\mathrm{KCl}$ standard solution.

Surface water samples were taken from the $\mathrm{R} / \mathrm{VCa}$ ruana while underway using a clean plastic bucket attached to a nylon rope. Temperatures and salinities were measured immediately as discussed above and the samples were subsequently transferred to 1-liter polyethylene bottles. Hydrocasts were taken using homemade water samplers (Wolgemuth and Ribeiro, 1979). Samples listed as "Bottom Trip" were taken with a water sampler designed to close when an attached rod hit bottom. These samples are from about $1 \mathrm{~m}$ off the bottom.

The water samples were filtered through preweighed $47 \mathrm{~mm}$ Nuclepore filters $(0.4 \mu \mathrm{m}$ pore size) upon return to the laboratory. Samples were washed free of sea salts with $50 \mathrm{ml}$ of distilled water. After drying at approximately $60^{\circ} \mathrm{C}$ overnight, the filters were left to equilibrate in a constant temperature weighing room. Each filter was weighed on a Mettler $\mathrm{H} 20$ Microbalance until a constant weight (within $0.05 \mathrm{mg}$ ) was obtained. Control filters were run by placing two preweighed filters together and filtering as usual. The top filter will effectively collect all of the particulates with the bottom one acting as the control. This procedure was repeated on approximately every tenth sample. The average- weight change of all the control filters was within the analytical uncertainty of our balance (about $\pm 0.05 \mathrm{mg}$ ). A slight weight loss was noted most often on these filters, perhaps indicating a partial solution of the polycarbonate during the filtering procedure.

Bottom sediments Bittencourt et al. (1976) reported on the distribution of bottom sediments according to sedimentological facies, carbonate composition, organic content, textural types, clay content, and size distribution. Fig. 3 presents a summary of their work. The sediments can be grouped into three types: 1) recent olive gray mud facies occurring in the northern half of the bay in shallow and calm waters; 2) relict yellowish gray quartz sand facies occupying the two channels through which circulation with the open sea is maintained; and 3) $p a$ limpsest facies consisting of: $a$ ) small isolated patches of biodetrital sediments, and $b$ ) mixed quart $z$ sand, mud and biodetrital material found in the central part of the bay and at the mouth of the Paraguaçu River. The biogenic deposits consist mainly of corroded and perforated mollusc shells and the bank to the south of Maré Island can be easily seen on Fig. 3 (Bittencourt et al., 1976).

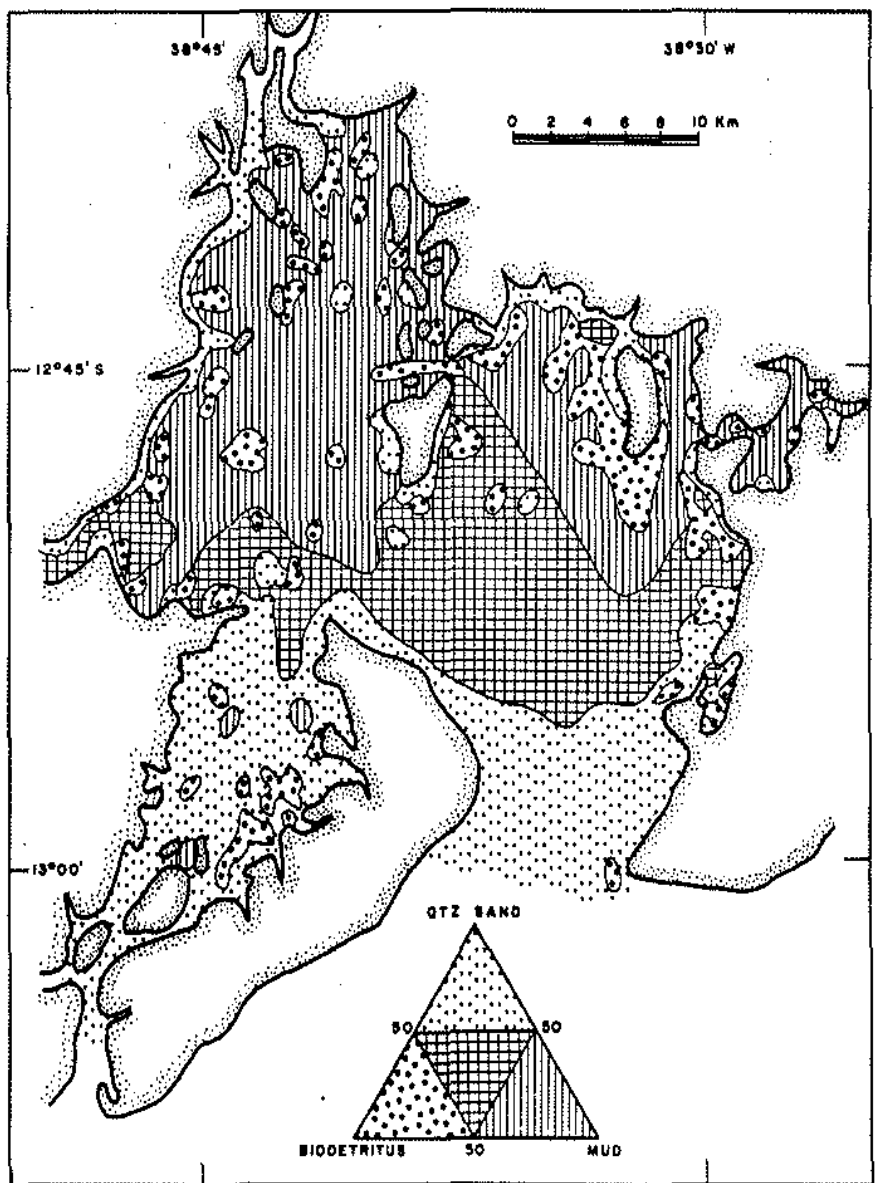

Figure 3 - Distribution of sediment facies (from Bittencourt et al., 1976) 
Oceanographic results THE $B A Y$ The salinity distribution for May 16-18, 1977 is shown in Fig. 4. Our other cruise which provided the most complete coverage of salinity data was on September 15-17, 1977. The results were almost identical to those shown in Fig. 4. The average of the salinity measurements in the western bay is $35.2 \%$ while the average at the entrance to the bay is $36.6 \%$, which we consider most typical of Atlantic Ocean water entering the bay. Therefore, it is clear that water in the western bay has less than a $5 \%$ component of fresh water from the Paraguaçu River.

Profiles of temperature and salinity showed that the bay is well-mixed vertically and does not display significant density stratification. Ten temperature profiles had $1.1^{\circ} \mathrm{C}$ or less difference between the surface and bottom, from $20-30 \mathrm{~m}$ depth. Six salinity profiles had $1.3 \%$ or less difference between the surface and bottom. Only one profile in the open bay near the mouth of the Paraguaçu River had surface salinity of $2.7 \%$, less than bottom water, the largest vertical difference that we observed.

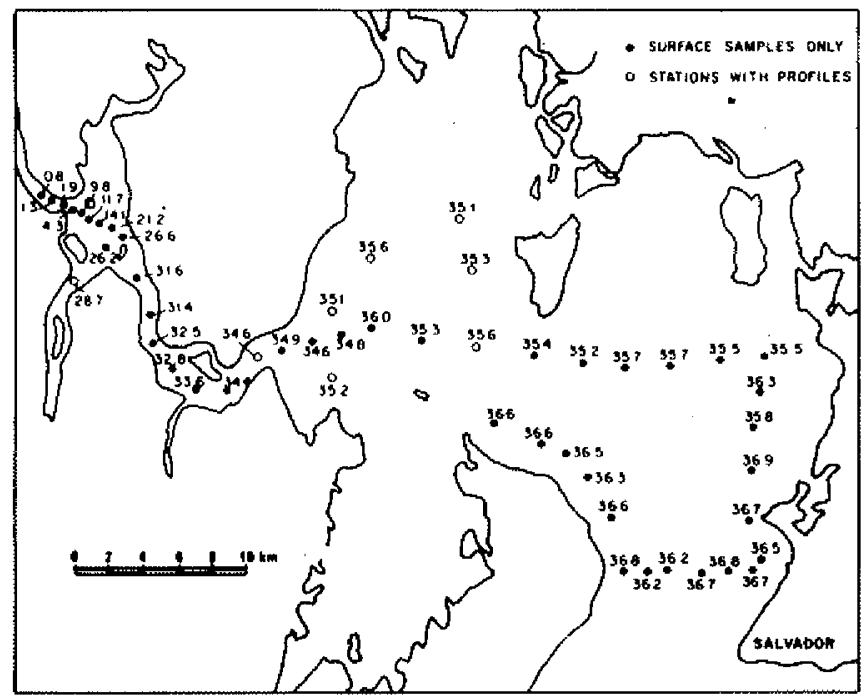

Figure 4-Salinity distribution during May 16-18, 1977. Open circles $(0)$ are profile stations and solid dots $(\bullet)$ surface collected samples. The salinity distribution was very similar to this on September 15-17, 1977

PARAGUACU RIVER Estuarine conditions within the study area occur predominantly within the channel of the Paraguaçu River, Fig, 4 includes the salinity measurements in the river channel as measured on May 16 and 17 , 1977. Results from two other cruises up the river to fresh water on March 2-3 and September 15-16, 1977, revealed essentially the same salinity distribution. In the lower ri* ver $(\mathrm{km}=0$ to 16$)$, we observed mixing between $S=$ $30 \%$ and $35 \%$. Iguape Bay ranged between $S=5 \%$ and $30 \%$. On all three cruises, we measured fresh water within $3 \mathrm{~km}$ upstream from Iguape Bay. Naturally, instantaneous salinity is governed by tidal stage as well as river discharge. We have not as yet monitored the salinity through a complete tidal cycle. Average daily and monthly discharge values for the Paraguaçu for the time interval covered by our study are shown as histograms in Fig. 5.

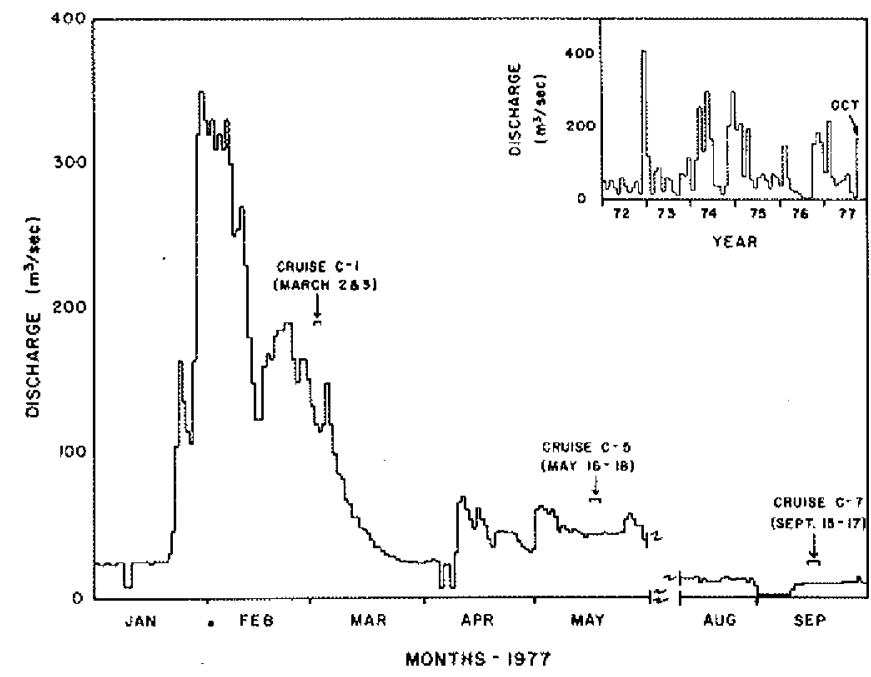

Figure 5 - Average daily discharge of the Paraguacu River. This hidrograph was prepared from average daily gauge height at a gauging station at $\mathrm{km}=50$, close to the proposed Pedro do Cavalo dam. The rating curve was drawn from about thirty discharge measurements over a 2-year period. (Data courtesy of Desenvale, the agency responsible for planning the development of the Paraguacu River valley)

Inset: Average monthly discharge for the Paraguacu River, 1972-1977 ( $\left.\mathrm{m}^{3} / \mathrm{sec}\right)$. High monthly discharges were $550 \mathrm{~m}^{3} / \mathrm{sec}$ (January, 1970), $750 \mathrm{~m}^{3} / \mathrm{sec}$ (March, 1969), and $1,500 \mathrm{~m}^{3} / \mathrm{sec}$ (Jonuary, 1964). The highest daily discharge recorded was 6,253 $\mathrm{m}^{3} / \mathrm{sec}$ in 1964 and the calculated long term average discharge is $112 \mathrm{~m}^{3} / \mathrm{sec}$ (Data before January, 1976, were obtained from Desenvale. For 1976 and 1977, discharge was calculated from daily gauge height records and periodic discharge measurements by preparing a rating curve)

Table I - Monthly surface temperature and salinity data at the mouth of the Paraguacu River from July, 1973, to June, 1974. (Peixinho, personal communication). The last two columns are the average monthly rainfall and air temperature at a meteorological station at the Salvador airport from 1961 to 1970 (Neyde, personal communication)

\begin{tabular}{|c|c|c|c|c|}
\hline Month & $\begin{array}{c}T\left({ }^{\circ} \mathrm{C}\right) \\
\text { (for July, }\end{array}$ & $\begin{array}{l}S(\%) \\
\text { une, } 74)\end{array}$ & $\begin{array}{l}\text { Average monthly } \\
\text { rainfall } \\
\text { (mm for 1961-70) }\end{array}$ & $\begin{array}{c}\text { Air } \\
\text { Temperature } \\
\text { Averages }\left({ }^{\circ} \mathrm{C}\right)\end{array}$ \\
\hline July & 28.0 & 30.6 & 135 & 24 \\
\hline Aug & 26.9 & 32.5 & 100 & 24 \\
\hline Sept. & 27.5 & 31.9 & 62 & 25 \\
\hline Oct. & 29.0 & 28.1 & 57 & 25 \\
\hline Nov. & 29.0 & 28.5 & 125 & 25 \\
\hline Dec. & 30.0 & 31.6 & 154 & 26 \\
\hline Jan. & 29.5 & 32.5 & 71 & 27 \\
\hline Feb. & 27.0 & 30.5 & 123 & 27 \\
\hline Mar. & 28.5 & 23.7 & 151 & 27 \\
\hline April & 27.0 & 29.5 & 197 & 26 \\
\hline May & 27.0 & 23.6 & 316 & 25 \\
\hline \multirow[t]{2}{*}{ June } & 24.0 & 28.7 & 184 & 24 \\
\hline & & & 1,396 & $\left.\begin{array}{l}\text { vear } \\
\text { rage }\end{array}\right\} 25.3$ \\
\hline
\end{tabular}


Table 1 shows monthly temperature and salinity measurements taken from July, 1973, to June, 1974 (Peixinho, personal communication), at the mouth of the river $(\mathrm{km}=0)$. The salinity results are all lower than the three samplings we made at that point, possibly because she measured salinity by an $\mathrm{AgNO}_{3}$ titration of $\mathrm{Cl}^{-}$. As expected, the range of values demonstrates the effect of discharge on salinity at the river mouth, in this case about $7 \%$.

Table 1 also includes monthly water temperature measurements that demonstrate the uniformity of temperature through the year. For comparison purposes, Table 1 includes the monthly averages of rainfall and air temperature at a meteorological station in Salvador for the period 1961-1970.

Some salinity and pH data From Pina (1976) suggest that extremely high river discharge has caused times when most of Iguape Bay is filled with fresh water. It is unknown how often this type of mixing occurs and how long it persists until tidal flushing carries sea water into this section of the river.

Total suspended matter THE $B A Y$ The surface distribution of Total Suspended Matter (TSM) in the bay and the Paraguaç River during the cruise of May 16-18 is shown in Fig. 6. A similar distribution also occurred in March and September. Averages of. different regions of the bay are presented in Table 2 , both for surface samples only and also for surface samples plus profiles. In the eastern bay; values ranged generally from 0.5 to 2.0 $\mathrm{mg} / \mathrm{l}$ with an average of $1.5 \mathrm{mg} / 1$. Vertical profiles of suspended material are shown in Fig. 7. Many of these profiles display increased concentration with depth, of ten with the deepest sample having the highest concentration. The average of 99 surface and profile samples from the eastern bay, excluding Bottom Tripped ones, is $1.5 \mathrm{mg} / \mathrm{l}$.

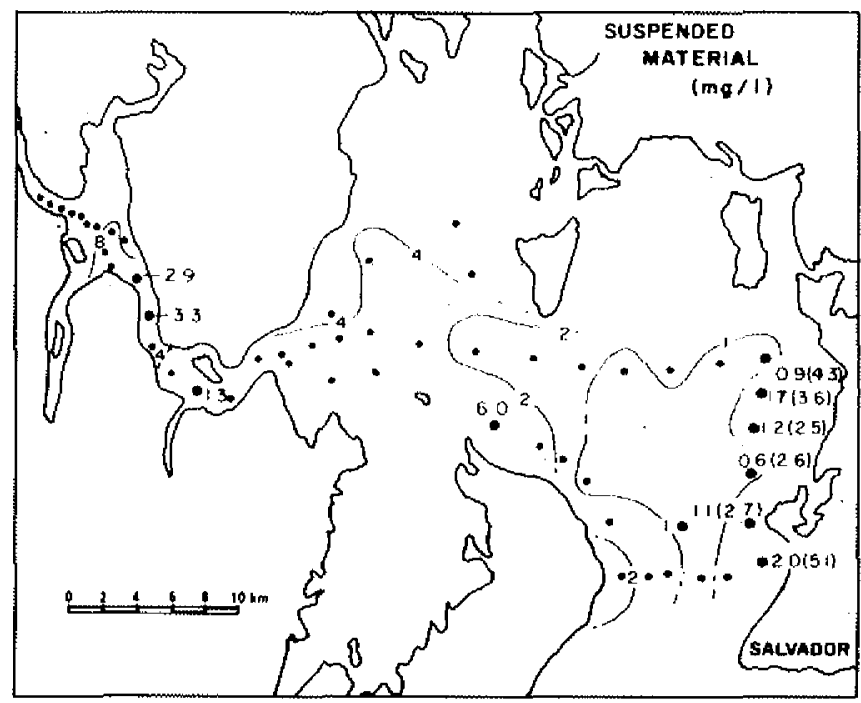

Figure 6 - Total suspended matter on May 16-18, 1977. Numbers in parentheses are values obtained on May 20 after a day of rain on the $19^{t h}$.
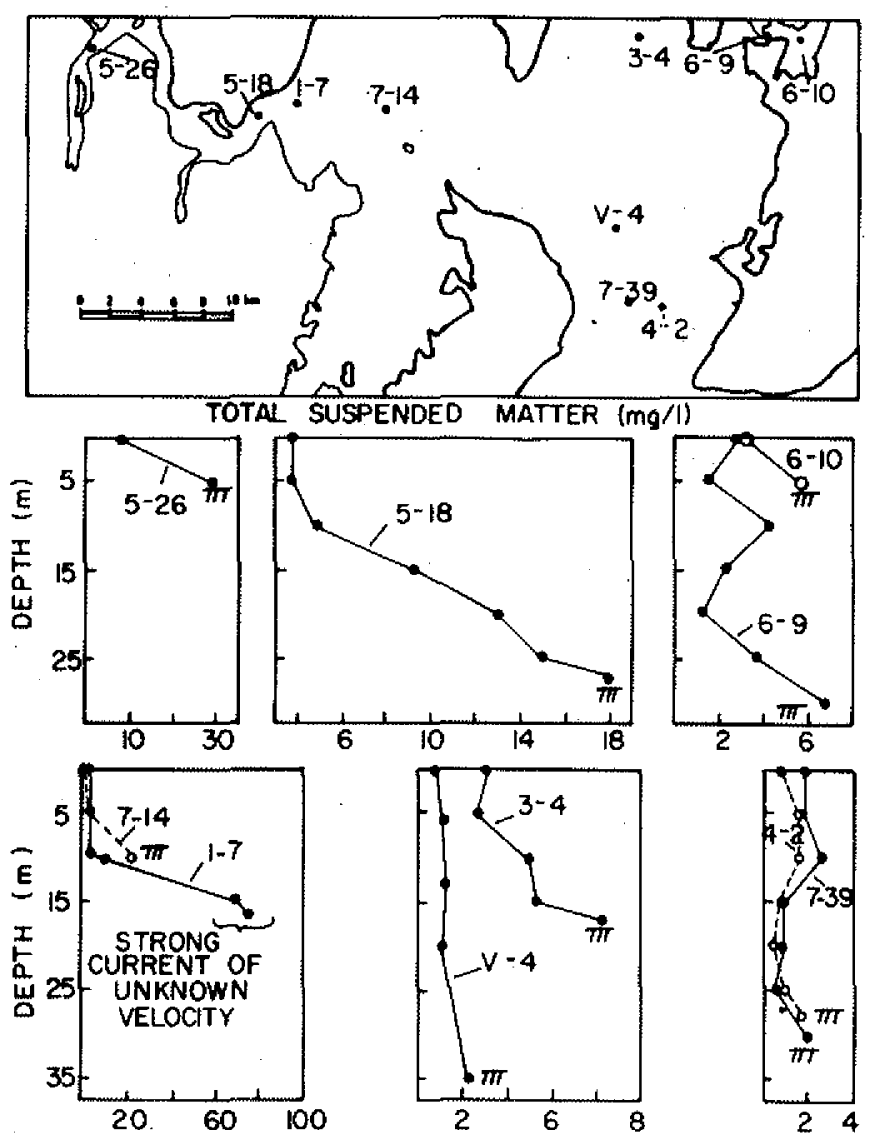

Figure 7 - Vertical profiles of Total Suspended Matter (TSM) in various sections of the bay. The symbol " $M$ " signifies that the sample just above was collected with a sampler equipped with a mechanism that closed when it hit bottom. These samples were taken from about $1 \mathrm{~m}$ from the bottom

From the work of Schubel (1969) and d'Anglejan and Smith (1973), we might expect increased turbidity in bottom samples due to resuspension by tidal currents. Several of the profiles in Fig. 7 would suggest this possibility. In order to evaluate effects of tidal currents on total suspended load, two stations were occupied during a part of the tidal cycle and samples collected about $1 \mathrm{~m}$ off the bottom with the "Bottom Trip" sampler. Fig. 8 shows that at 7-39, which TSM did in fact increase by a factor of $\sim 4$ between low and high tides. However, at station V-4, TSM did not change between currents of $10 \mathrm{~cm} / \mathrm{s}$ and 75 $\mathrm{cm} / \mathrm{s}$. Apparently a sandy bottom occured at this station. Our best evidence of increased turbidity due to surface runoff was a sampling on May 20 , after a day of heavy rain on the 19th. We were able to reoccupy many of the same stations in the eastern bay from cruise C5 on cruise C6, one day after an exceptionally heavy rain in the Salvador area. The number in parentheses in Fig. 6 represents surface values of six samples with an average of $3.5 \mathrm{mg} / 1$. Four days earlier, these same locations averaged 1.3 $\mathrm{mg} / \mathrm{l}$.

In the western bay, surface values average $3.4 \mathrm{mg} / \mathrm{I}$ (Fig. 6 and Table 2). This part of the bay is generally shal- 
Table 2 - Averages of total suspended matter in different parts of the Bay. All cruises were during periods without heavy rain except as noted

\section{SURFACE SAMPLES}

\begin{tabular}{|c|c|c|c|}
\hline Locale & $\begin{array}{l}\text { No. of } \\
\text { samples }\end{array}$ & $\operatorname{TSM}(\mathrm{mg} / \mathrm{l})$ & Remarks \\
\hline Eastern Bay & 48 & 1.5 & See Fig. 7 \\
\hline Western Bay & 16 & 3.4 & See Fig. 7 \\
\hline $\begin{array}{l}\text { C5 samples } \\
\text { (eastern edge } \\
\text { of Bay) }\end{array}$ & 6 & 1.3 & C5 samples were taken on May 16 \\
\hline $\begin{array}{l}\text { C6 samples } \\
\text { (eastern edge } \\
\text { of Bay) }\end{array}$ & 6 & 3.5 & C6 samples were taken on May 20 after heavy rain on the 19 th \\
\hline Lower Paraguaçu & 12 & 3.1 & $\begin{array}{l}\text { All samples between } \mathrm{km}=0 \text { and } \mathrm{km}=16 \text { except two high values apparently in- } \\
\text { fluenced by falling tide }\end{array}$ \\
\hline Upper Paraguaqu & 6 & 16.0 & March 3 samples from $S<20 \%$. High value at zero salinity wảs $25 \mathrm{mg} / \mathrm{l}$ \\
\hline Upper Paraguaçu & 11 & 41.0 & $\begin{array}{l}\text { May } 17 \text { and Sept. } 16 \text { from samples with } S<20 \% \text {. Highest values at low salinity } \\
\text { on both days was between } 65 \text { and } 70 \mathrm{mg} / \mathrm{l}\end{array}$ \\
\hline
\end{tabular}

PROFILES - excluding Bottom Tripped samples

$\begin{array}{llll}\text { Eastern Bay } & 99 & 1.5 & \begin{array}{l}\text { Includes surface samples. All profiles except 7-7, 7-10, 3-4, and 4-3 which were } \\ \text { near the margins of the Bay and had distinctly higher values }\end{array} \\ \text { Western Bay } & 27 & 3.8 & \begin{array}{l}\text { Excluded } 50 \mathrm{mg} / 1 \text { of } 5-4 \text { and the } 3 \text { bottom samples } 1-7 \text { which clearly had a strong } \\ \text { current }\end{array} \\ \text { Aratu Bay } & 26 & 3.9 & \text { All except } 189 \mathrm{mg} / \mathrm{l} \text { of sample } 35 \mathrm{~F}\end{array}$
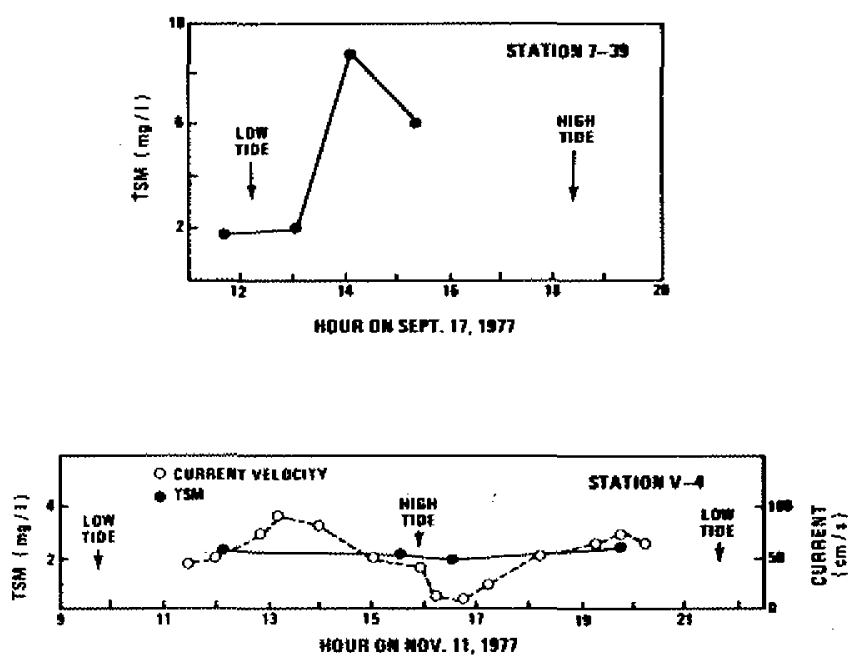

Figure 8 - TSM in near bottom samples compared to the tidal cycle. These sample were collected by a sampler with a triggering mechanism that closed when the sampler touched bottom, collecting the water about $1 \mathrm{~m}$ above the bottom. Station 7.39 showed a four-fold increase of TSM during maximum tidal cur. rent, suggesting a muddy bottom. In contrast, station V-4, which includes current data obtained with a rotor type current meter, shows no change in TSM throughout the tidal cycle. Station V-4 was taken during spring tides with a maximum amplitude in the port of Salvador of $2.6 \mathrm{~m}$. The locations of stations 7-39 and V-4 are shown in the index map of Fig. 7 lower, is characterized by finer-grained sediments and more material is resuspended by tidal currents. Profiles $5-18,1-7$, and 7-14 in Fig. 7 all show clear evidence of increased turbidity in near bottom samples.

Aratu Bay was sampled most thoroughly on May 20 after a day of rain. The profiles in Fig. 7 and a compilation of average values in Table 2 give an average of $3.9 \mathrm{mg} / \mathrm{l}$.

PARAGUACU RIVER In the lower Paraguaçu from $\mathrm{km}=0$ to $\mathrm{km}=16$, TSM averaged $3.1 \mathrm{mg} / \mathrm{l}$ (Table 2) or somewhat less than the western bay. This may imply a turbidity maximum similar to that described by Schubel (1968) although the small increase does not make the phenomena clearly defined. At the mouth of the river at $\mathrm{km}$ $=0$ we obtained a good vertical profile at station 5-18 that shows regular increase with depth (Fig. 7) reflecting resuspension during a strong ebb current.

In the upper Paraguaç with low salinity water ( $\mathrm{S}<20 \%$ ), suspended material averaged $41 \mathrm{mg} / 1$ (range 20 to $70 \mathrm{mg} / \mathrm{l}$ ) for the samplings during May and September. The sampling in March had an average of $16 \mathrm{mg} / 1$ (see Table 2). The average daily discharge of the Paraguaçu is shown in Fig. 5 with the cruises to the river superimposed. It is surprising that the TSM of the March sampling $(16 \mathrm{mg} / \mathrm{l})$ was lower than the others since the discharge was higher than during our the other sampling. However, in this river the rate of supply of particulate matter is not high (erosion rate low) and so this may be a dilution effect. 


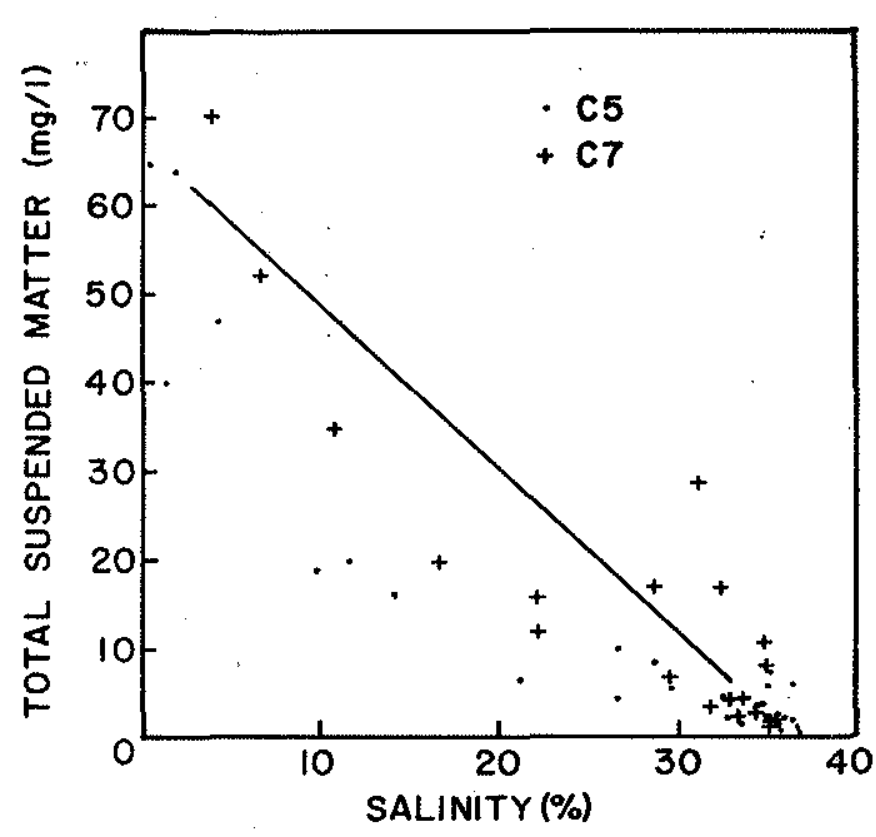

Figure 9 - Plot of Total Suspended Matter versus salinity for cruises $C 5$ and $C 7$

Fig. 9 shows a plot of suspended material versus salinity in an attempt to demonstrate the loss of sediment within the estuary. Since most points of intermediate salinity fall below the theoretical mixing line between fresh and marine water, it is clear that suspended particulates behave as a non-conservative parameter in this area. It is likely that Iguape Bay acts as a settling basin where large fractions of the particulates are trapped.

CONCLUSIONS The salinity distribution in Todos os Santos Bay demonstrates that it is dominated almost entirely by sea water from tidal flushing. Estuarine conditions occur only within the channel of the Paraguaçu River. Fresh water entering the bay has a suspended load of $20-70 \mathrm{mg} / 1$. It is approximately inversely related to river discharge. This sediment is effectively removed before entering the main part of the bay where the suspended load is $0.5-2.0 \mathrm{mg} / \mathrm{l}$. The character of the vertical profiles indicates that resuspension of bottom sediment occurs with strong tidal currents, depending on the occurrence of fine sediment on the bottom.

From our preliminary work on the oceanographic and suspended sediment conditions in Todos os Santos Bay, several areas where further investigation would be useful have been identified:

- Monitor salinity and total suspended matter through a complete tidal cycle in the open bay and at the mouth of the Paraguaçu River.

- Further characterize mixing within the bay by chemical parameters, especially nutrients such as silica.

- Investigate probable seasonal differences which would be expected due to changes in productivity.

Acknowledgements The first two authors want to thank Profs. C. A. Dias and Y. Ferreira for arranging faculty appointments at the Federal University of Bahia with funding from Finep. A scholarship from Capes provided support for the third author during his graduate studies.

The first author wishes to thank the Department of Oceanography at the Florida State University for a temporary appointment during the spring quarter, 1978, which provided an opportunity to work on this paper and collaborate on elemental analyses of the suspended material.

A. C. S. P. Bittencourt assisted by preparing the $R / V$ Caruana for several cruises and R. F. Ribeiro helped to collect samples. The average rainfall and temperature data for Salvador were kindly provided by Profa. Neyde of the Department of Geography, Institute of Geoscience, UFBa. Profa. Peixinho of the Institute of Biology kindly provided the temperature and salinity data from the mouth of the Paraguaçu River. A. Coutinho and S. Leukanech drafted the figures. $H$. Wolgemuth helped to filter the samples. H. Wolgemuth, B. Crocco and S. Showell typed through many editions of the manuscript.

\section{REFERENCES}

BARRETO, H.T. and SUMMERHAYES, C.P. - 1975 - Oceanography and suspended matter off Northeastern Brazil, Jour Sed. Petrology 45: 822-833.

BITTENCOURT, A.C.S.P., BRICHTA A., and Di NAPOLI, E. - $1974-$ A Sedimentaçăo na Baía de Aratu, Bahia, Revista Brasileira de Geociências 4 : 51-63.

BITTENCOURT, A.C.S.P., FERREIRA, Y and Di NAPOLI, E. - 1976 - Alguns aspectos da sedimentação na Baia de Todos os Santos, Bahia, Revista Brasileira de Geociências 6: 246-262.

BENNINGER, L.K., LEWIS, D.M., and TUREKIAN, K.K. - 1975 - The use of natural $\mathrm{Pb}-210$ as a heavy metal tracer in the river-estuarine system, in $\mathrm{T}$. Church (ed.), Marine Chemistry in the Coastal Environment, ACS Symposium Series 18, American Chemical Society, 202-210.

BURNETT, W.C. (in preparation) - Elemental analyses of suspended sediments from a Brazilian estuary.

D'ANGLEJAN, B.F. and SMITH, E.C. - 1973 - Distribution, transport, and composition of suspended matter in the St. Lawrence estuary, Can. J. Earth Sci, 10: 1380-1396.

PINA, L.C. - 1976 - Estudo do Comportamento dos Elementos C, O, e Mg no Estuário do Rio Paraguaçu - Bahia. Tese de Mestrado, Programa de Pesquisa e Pós-Graduação em Geofísica, Universidade Federal da Bahia, Salvador, Bahia.

SCHUBEL, J,R, - 1968 - Turbidity maximum of the Northern Chesapeake Bay, Science 161: 1013-1015.
SCHUBEL, J.R. - 1969 - Size distributions of the suspended particles of the Chesapeake Bay turbidity maximum, Netherlands Journal of Sea Research 4: 283-309.

SCHUBEL, J.R. - 1971 - The Estuarine Environment - Estuaries and Estuarine Sedimentation. American Geological Institute, Short Course Lecture Notes.

SCHUBEL, J.R. - 1972 - Distribution and Transportation of Suspended Sediment in Upper Chesapeake Bay, GSA Memoir 133.

SCHUBEL, J.R. and HIRSCHBERG, D.J. - 1976 - Pb-210 determined sedimentation rate, and accumulation of metals in sediments at a station in the Chesapeake Bay, Chesapeake Science.

TAVARES, T.M., PESO, M.C. and SOUZA, S.P. - 1977 - Estudo da Distri. buiçăo de Mercúrio na Água, Sedimentos e Moluscos da Enseada dos Tainheiros, Resumos da 29: Reuniăo Anual, Sociedade Brasileira para o Progresso da Ciência, 544 .

WOLGEMUTH, K. and RIBEIRO, R.F. - 1979 - Construçăo e uso de um amostrador de água com capacidade para 2 litros, Revista Brasileira de Tecnologia 8: 213-221. 